\title{
STEGANOGRAFI DALAM FILE CITRA \\ MENGGUNAKAN FUNGSI HASH DAN METODE \\ MLSB
}

\section{TUGAS AKHIR}

Diajukan Untuk Memenuhi

Persyaratan Guna Meraih Gelar Sarjana Strata 1

Teknik Informatika Universitas Muhammadiyah Malang

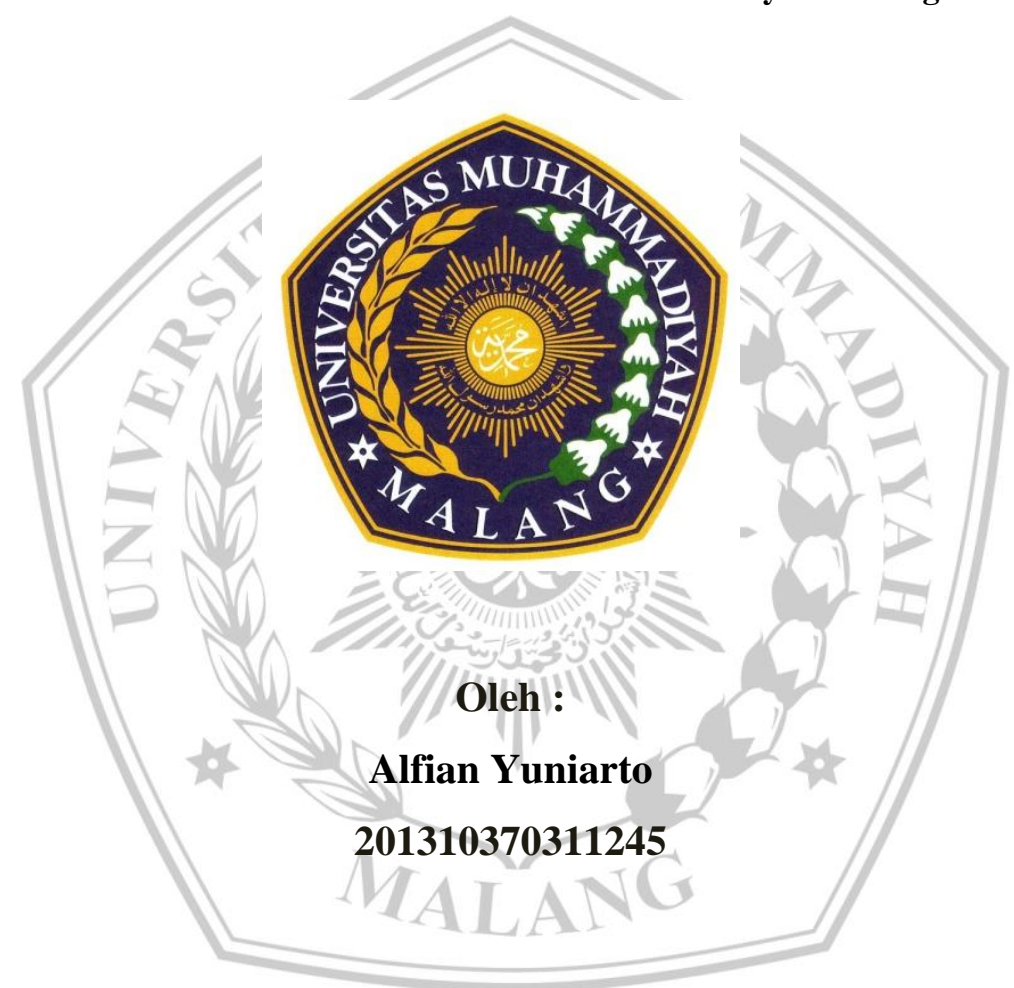

PROGRAM STUDI INFORMATIKA

FAKULTAS TEKNIK

UNIVERSITAS MUHAMMADIYAH MALANG

2020 


\title{
LEMBAR PERSETUJUAN
}

\section{STEGANOGRAFI DALAM FILE CITRA MENGGUNAKAN FUNGSI \\ HASH DAN ALGORITMA MLSB}

\author{
Alfian Yuniarto \\ 201310370311245
}

Telah Direkomendasikan Untuk Diajukan Sebagai Judul Tugas Akhir Di

Program Studi Informatika Universitas Muhammadiyah Malang
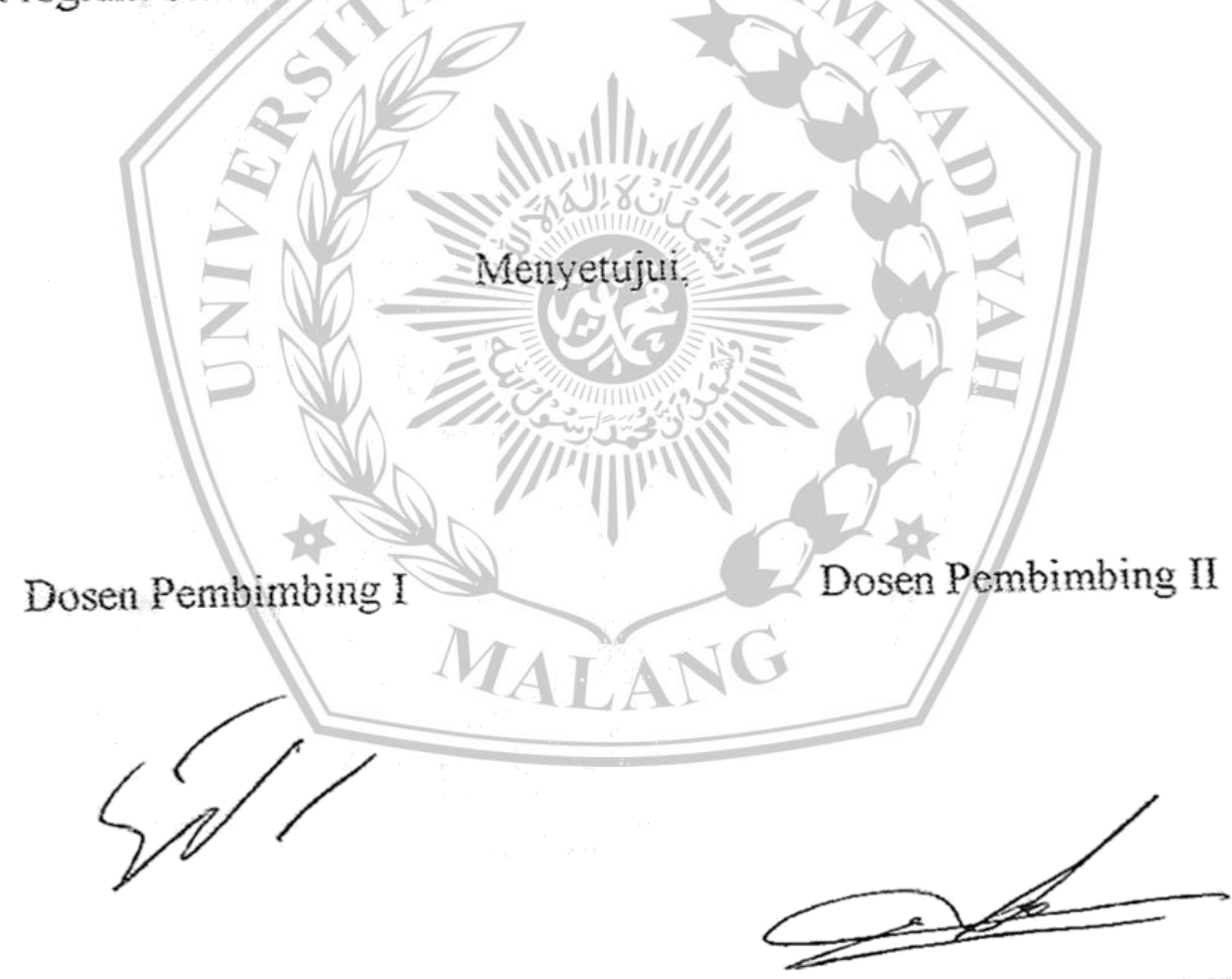

Eko Budi Cahyono, S.kom, M.T Agus Eko Minarno, M.Kom NiP. 108.9504 .0330 NIP. 108.1410 .0540 


\section{LEMBAR PENGESAHAN}

STEGANOGRAFI DALAM FILE CITRA MENGGUNAKAN FUNGSI

HASH DAN METODE MLSB

TUGAS AKHIR

Diajuakan Untuk Memenuhi

Persyaratan Guna Meraih Gelar Sarjana Strata 1

Teknik Informatika Universitas Muhammadiyah Malang

Disusun Oleh:

Alfian Yuniarto

201310370311245

Tugas Akhir ini telah diuji dan dinyatakan lulus melalui sidang majelis penguji

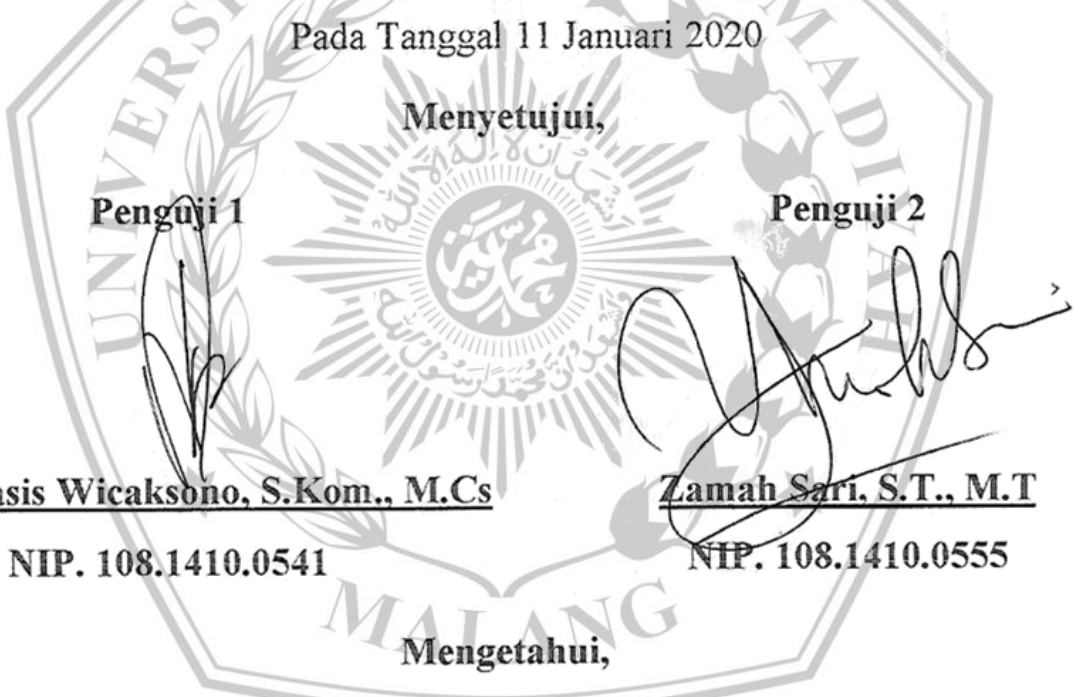

Galih Wasis Wicaksono, S.Kom., M.Cs

Zamah Sgri, S.T., M.T

NIP. 108.1410.0541

Mengetahui,

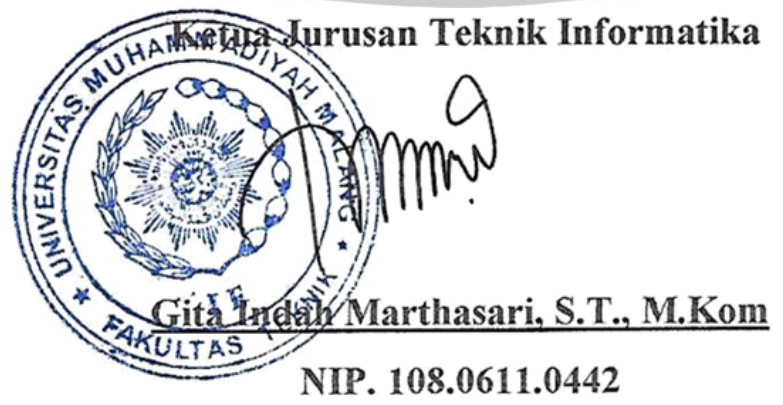




\section{LEMBAR PERNYATAAN}

Yang bertanda tangan di bawah ini:

$\begin{array}{ll}\text { Nama } & \text { : Alfian Yuniarto } \\ \text { Tempat, Tanggal Lahir } & \text { : Trenggalek, } 19 \text { juni } 1995 \\ \text { NIM } & : 201310370311245 \\ \text { Fakultas / Jurusan } & \text { : Telsnik/ Teknik Informatika }\end{array}$

* Dengan ini saya menyatakan bahwa Tugas Akhir dengan judul "STEGANOGRAFI DALAM FILE CITRA MENGGUNAKAN FUNGSI HASH DAN ALGORTMA MLSB " berserta isinya adalah karya saya sendiri dan bukan merupakan karya tulisan orang lain, baik sebagian maupun seluruhnya, kecuali bentuk kutipan yang telah disebutkan sumbernya.

Demikian surat pernyataan ini saya buat dengan sebenar-benarnya. Apabila kemudian ditemukan adanya pelanggaran terhadap etika keilmuan dalam karya saya ini, atau ada klaim dari pihak lain terhadap keaslian karya saya ini maka saya siap menanggung segala bentuk resiko/sanksi yang berlaku.

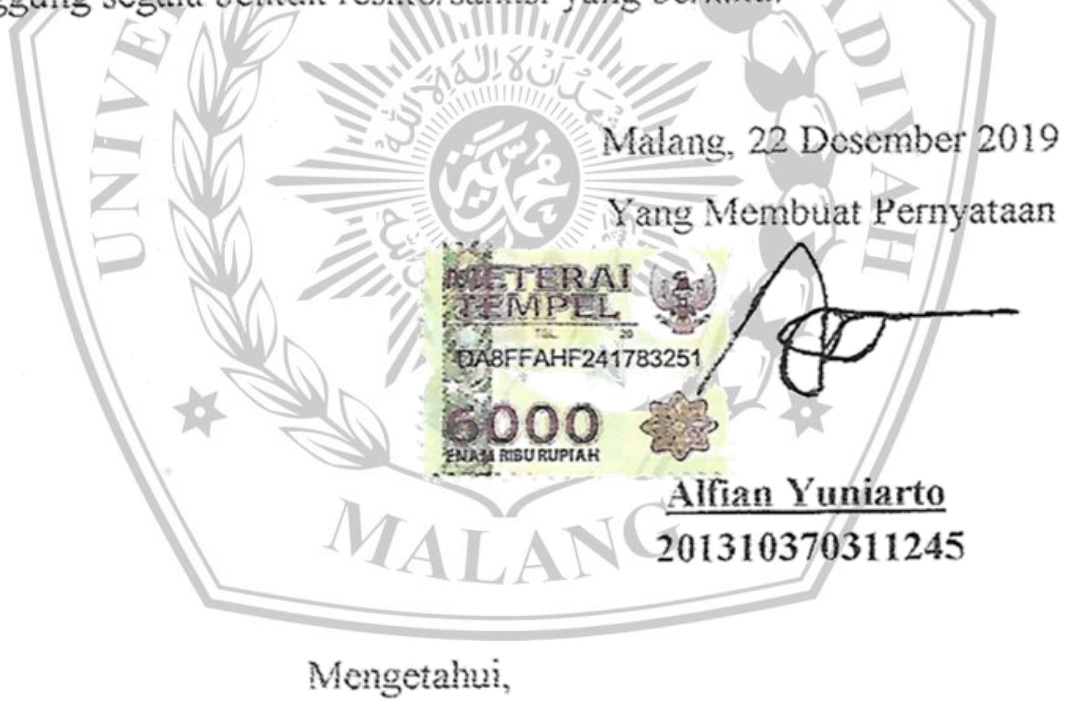

Dosen Pembimbing $\mid$

Dosen Pembimbing $/ 1$

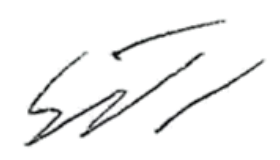

Eko Budi Cahyono, S.kom, M.T

NIP. 108.9504.0330

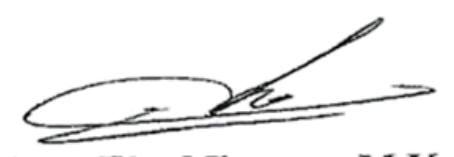

Agus Eko Minarno, M.Kom

NIP. 108.1410.0540 


\begin{abstract}
ABSTRAK
Semakin berkembangnya jaringan internet dapat mempermudah proses pertukaran informasi. Ketika suatu informasi bersifat rahasia ditransmisikan lewat jaringan komputer/internet, maka diperlukan jaminan bahwa informasi tersebut hanya dapat diakses oleh pihak yang berkepentingan. Permasalahan tersebut dapat di selesaikan dengan salah satu cara yaitu penyembunyian pesan dalam pengiriman adalah merubah data menjadi yang tidak dimengerti dengan cara di sisipkan ke dalam pixel yang dinamakan teknik steganografi. Pada Teknik steganografi ini salah satu metode yang dapat di gunakan adalah metode Modified Least Significant Bit (MLSB). MLSB merupakan pengembangan dari metode LSB yaitu dengan memodifikasi data dengan cara merubah dari 8 bit menjadi 5 bit. Selain metode MLSB tersebut kita juga dapat menggunakan fungsi hash MD5 sebagai tambahan pengamanan. Dengan menggunakan fungsi hash MD5 serta dengan menggunakan metode MLSB (modified least significat bit) ini kualitas dari file citra yang di hasilkan menunjukkan nilai baik karena dari rata - rata nilai dari gambar sampel dengan nilai MSE 0.0037 serta PSNR di atas $60 \mathrm{db}$.
\end{abstract}

Kata kunci : Steganografi, Modified Least Significant Bit, Message-Digest algortihm 5,PRNG. 


\begin{abstract}
Nowadays, people can be easy to acces the internet as changing information. People who wants to transfer information (undercover) through the internet, then the internet needs a guarantee that can only be accesed by profesional person. In sending hiden messages, we can changes the data that is not understood by inserting into pixels which is called by steganography techniques. Therefore, this steganography techniques used the modified least significant bit (MLSB) method. MLSB is the development of the LSB method. LSB method is modifying data be changing from 8 bit to 5 bit. In addition, we can also use the hash MD5 function as an ancillary security. Using both hash MD5 function and MLSB method showed a good result from quality of images file which hasthe average value of sample images with MSE 0,0037 balues and PSNR above 60dB.
\end{abstract}

Keywords : Steganography, Modified Least Significant Bit, Message-Digest algortihm, PRNG.

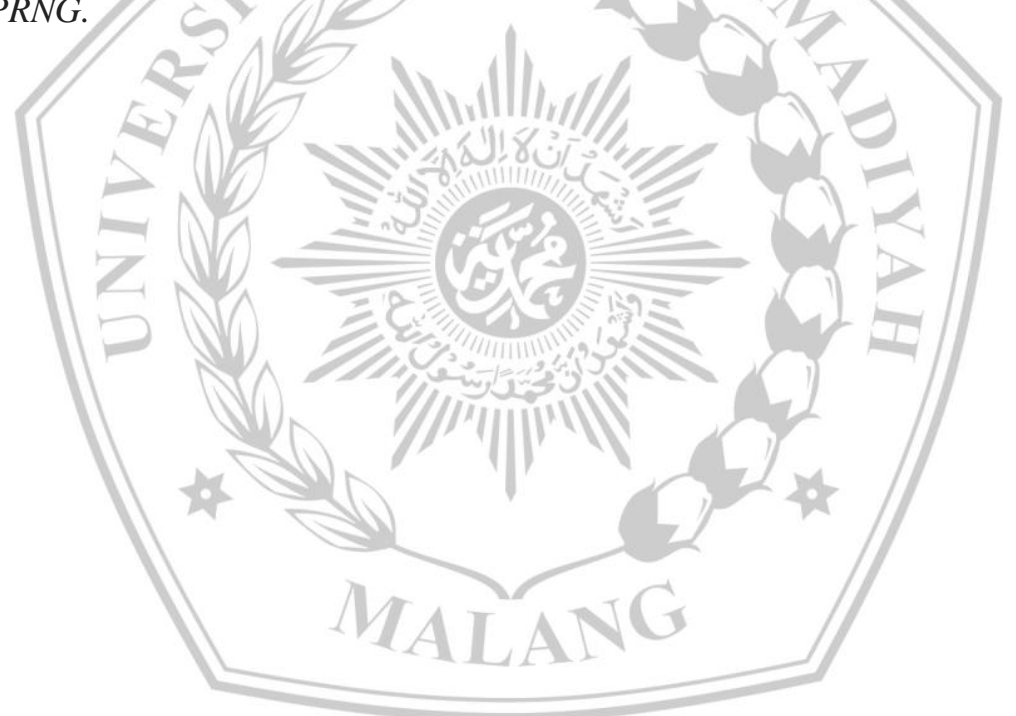


KATA PENGANTAR

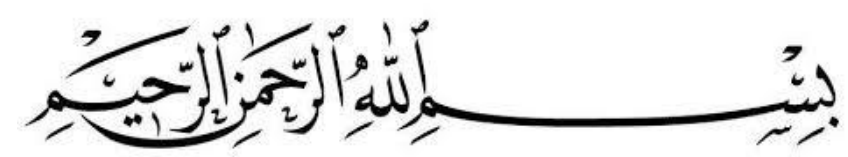

Segala puji bagi Allah SWT, yang telah memberikan Rahmat dan Karunianya, sehingga penulis dapat menyelesaikan tugas akhir yang berjudul:

\section{"Steganografi Dalam File Citra Menggunakan Fungsi Hash Dan Metode MLSB"}

Tugas akhir ini merupakan salah satu syarat studi yang harus ditempuh oleh seluruh mahasiswa Universitas Muhammadiyah Malang, guna menyelesaikan akhir studi pada jenjang program Strata 1.

Peneliti menyadari masih banyak kekurangan dan keterbatasan dalam penlisan tugas akhir ini. Untuk itu, penulis sangat mengharapkan saran yang sangat membangun agar tulisan ini dapat///berguna untuk perkembangan ilmu pengetahuan kedepan.

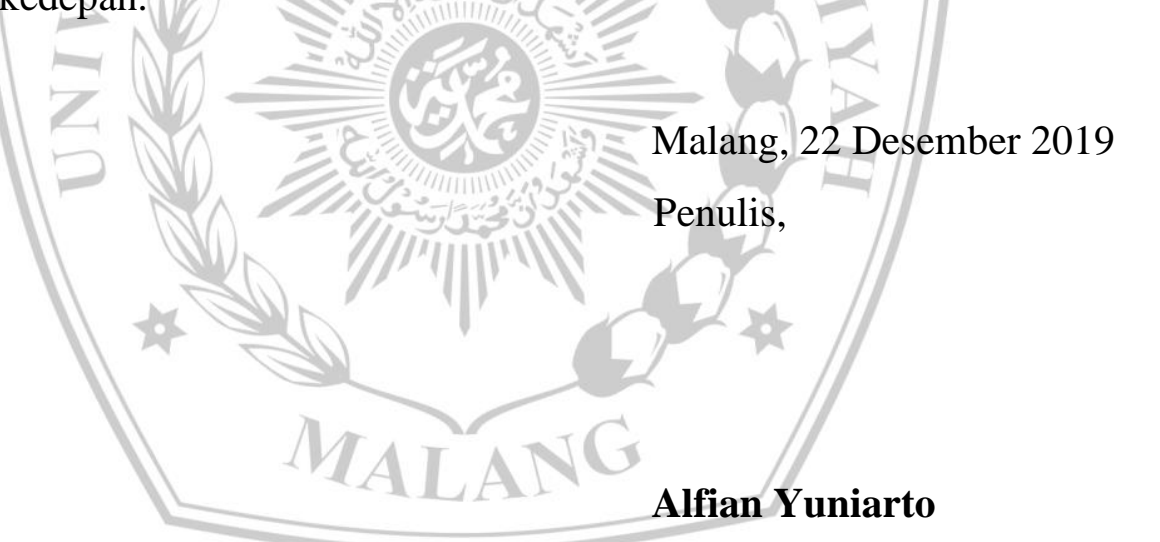




\section{LEMBAR PERSEMBAHAN}

Puji syukur kepada Allah SWT atas rahmat dan karunia nya sehingga penulis dapat menyelesaikan Tugas Akhir ini. Penulis menyampaikan ucapan terima kasih kepada :

1. Allah SWT yang selalu memberikan kesehatan dan petunjuk dalam pengerjaan tugas akhir ini.

2. Rasulullah Muhammad SAW. Imam dan penuntun menuju Al-Jannah. Kedua orang tua, Bapak Agus Kasman dan Ibu Mutini yang selalu sabar dan tiada henti mendoakan demi kesuksesan anaknya.

3. Bapak Eko Budi Cahyono, S.Kom, M.T dan Bapak Agus Eko Minarno, M.Kom. selaku dosen pembimbing tugas akhir ini.

4. Bapak Dr. Ahmad Mubin, ST., MTs elaku Dekan Fakultas Teknik Universitas Muhammadiyah Malang.

5. Ibu Gita Indah Marthasari, S.T., M.Kom. selaku Ketua Jurusan Teknik Informatika Universitas Muhammadiyah Malang.

6. Semua dosen pengajar di jurusan Teknik Informatika UMM yang telah memberikan ilmu yang sangat bermanfaat.

7. Seluruh staff dan karyawan di sekretariat Program Studi Teknik Informatika maupun karyawan Fakultas Teknik Universitas Muhammadiyah Malang yang telah membantu dalam/memberikan akses informasi dan memenuhi kewajibab dan hak administrasi selama perkuliahan.

8. Teman-teman Informatika F yang senasib sepenanggungan yang selalu saling bahu-membahu.

Kepada semuanya, hanya ungkapan terimakasih dan doa yang dapat penulis persembahkan. Semoga segala yang telah diberikan pada penulis bisa mendapatkan balasan yang setimpal dan memberikan kenangan yang tidak terlupakan. 


\section{DAFTAR ISI}

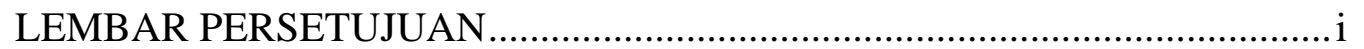

LEMBAR PENGESAHAN....................................................................... ii

LEMBAR PERNYATAAN ................................................................... iii

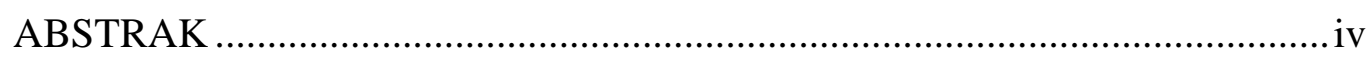

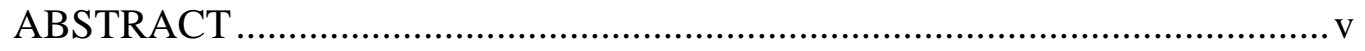

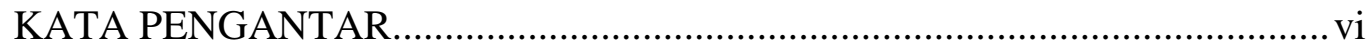

LEMBAR PERSEMBAHAN .......................................................................... vii

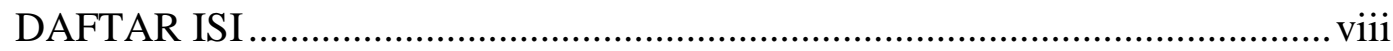

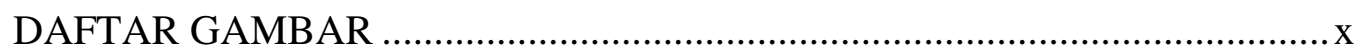

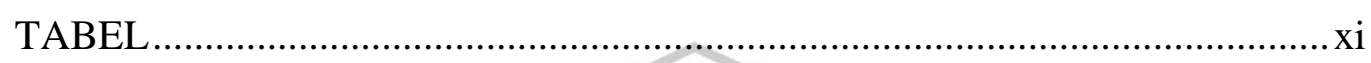

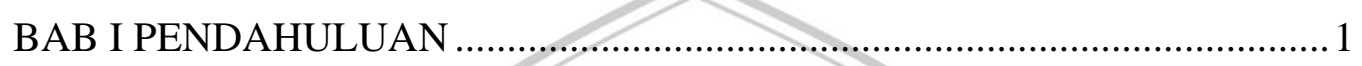

1.1 LATAR BELAKANG .......................................................... 1

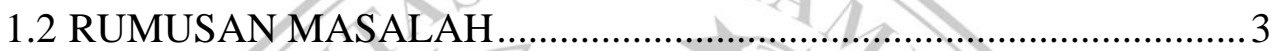

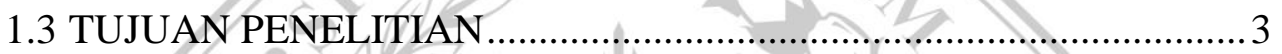

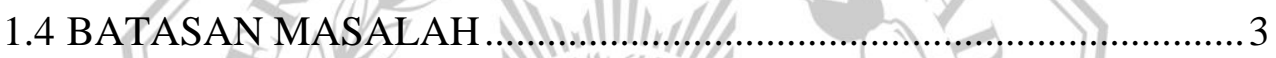

1.5 METODOLOGI................................................................ 4

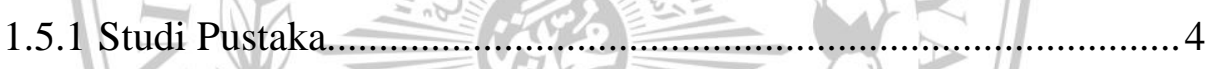

1.5.2 Rancangan Umum............................................................ 4

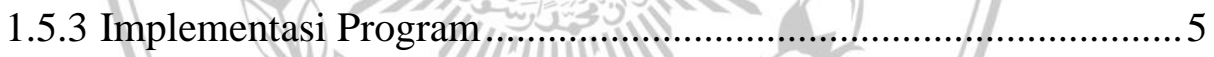

1.5.4 Pengujian Citra Hasil Steganografi........................................... 5

1.6 SISTEMATIKA PENULISAN ................................................... 6

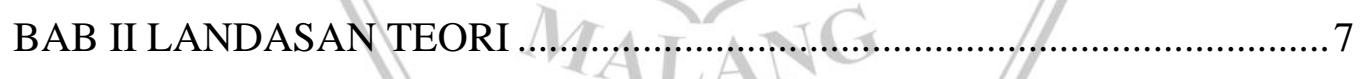

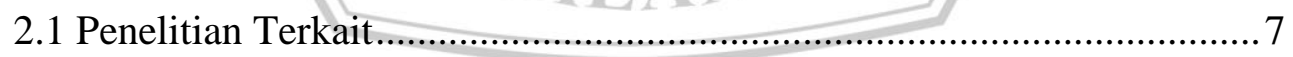

2.1.1 Modified Least Significant Bit (MLSB) .................................... 7

2.1.2 Steganografi pada Citra dengan Metode MLSB dan Enkripsi

Triple Transposition Vigenere Cipher

7

2.1.3 Achieving Security for Images by LSB and MD5 ...................... 8

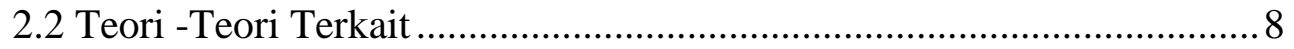

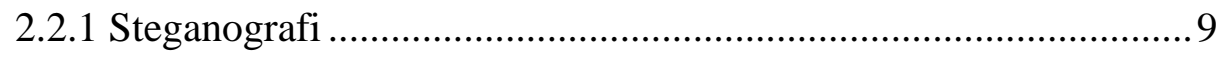

2.2.2 Hash Function ........................................................................ 13

2.2.3 Pseudo Random Number Generator(PRNG) ............................... 16 
2.2.4 Library Pengolahan Citra Digital................................................. 16

2.2.5 Peak Signal Noise Ratio(PSNR) .................................................. 17

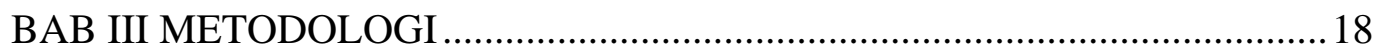

3.1 Analisa Metode yang digunakan ....................................................... 18

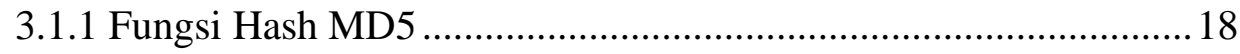

3.1.2 Penggunaan Algoritma MLSB................................................. 19

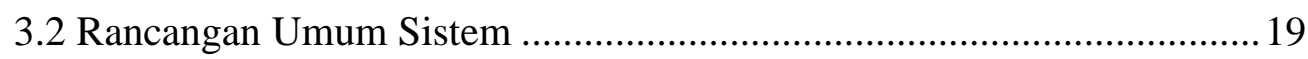

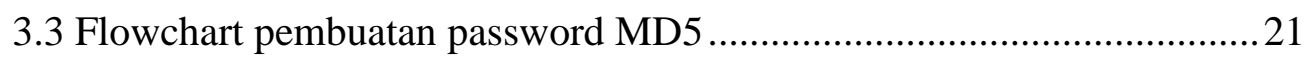

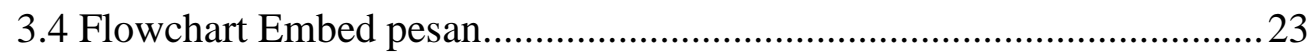

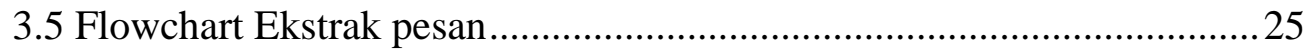

3.6 Landasan pengujian Hasil citra steganografi .........................................26

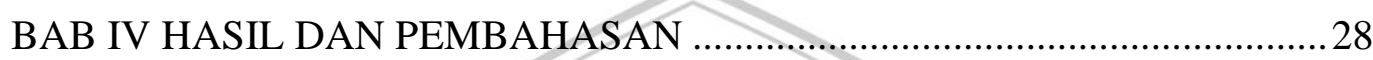

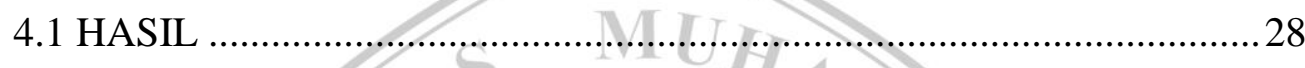

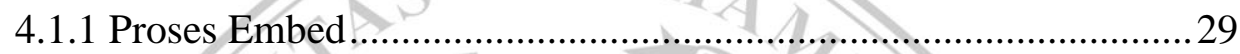

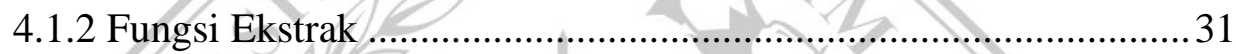

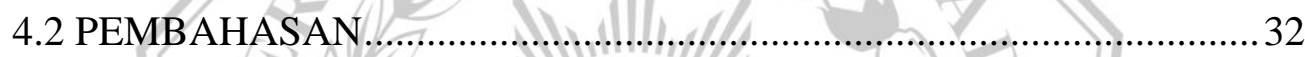

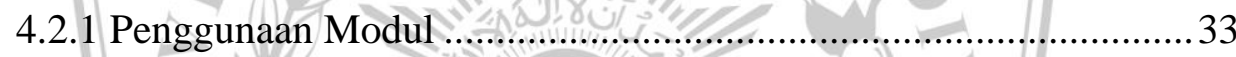

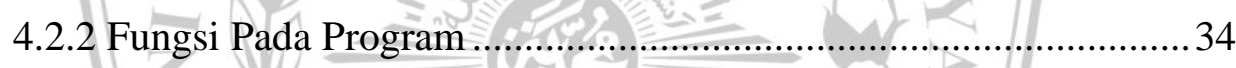

4.2.3 Hasil Pengujian MSE dan PSNR Triple Transposition Vigenere

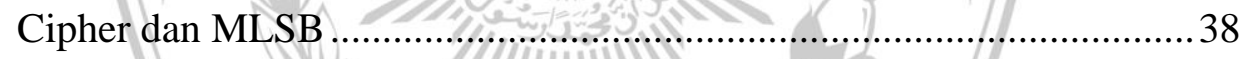

4.2.4 Hasil Pengujian MSE dan PSNR Meggunakan Fungsi Hash dan

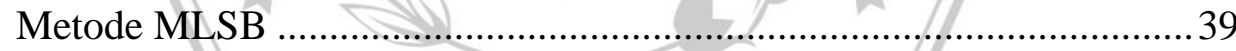

4.2.5 Pengujian Maksimal Input karakter Menggunakan Fungsi Hash dan

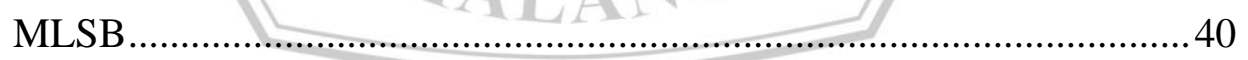

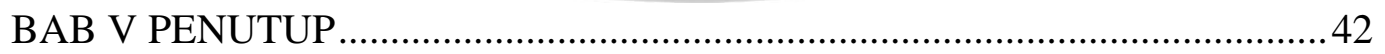

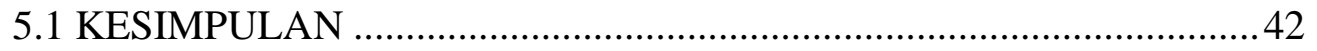

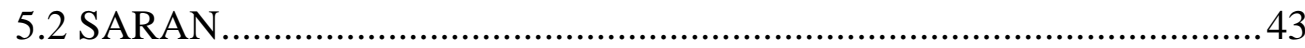




\section{DAFTAR GAMBAR}

Gambar 1.1 Rancangan umum program 4

Gambar 2.1 Flowchart Modified Least Significant Bit (MLSB)....... 13

Gambar 3.1 Skema Umum Penyisipan Pesan................................... 20

Gambar 3.2 Flowchart Pengolahan Password MD5 …....................... 21

Gambar 3.3 Flowchart Penyisipan Pesan............................................. 23

Gambar 3.4 Flowchart Ekstrak pesan ............................................... 25

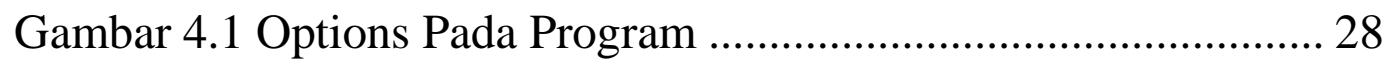

Gambar 4.2 Gambar Sampel Lena.png ............................................ 29

Gambar 4.3 Perintah Embed Pesan................................................... 30

Gambar 4.4 Gambar Hasil Stego Image Output.png ......................... 31

Gambar 4.5 Proses Ekstrak Pesan _.................................................. 32

Gambar 4.6 Source Code Fungsi Num2bit ........................................ 34

Gambar 4.7 Source Code Fungs convert2txt ................................... 35

Gambar 4.8 Source Code Fungsi get_bits........................................ 36

Gambar 4.9 Source Code Fungsi get_hex_bits................................ 36

Gambar 4.10 Source Code Fungsi Embed Penyisipan Pesan ............ 37

Gambar 4.11 Source Code Fungsi Extract Pesan .......................... 37

Gambar 4.12 Source Code Pemanggilan Fungsi MD5 ..................... 38 


\section{DAFTAR TABEL}

Tabel 3.1 Sampel pengujian MSE dan PSNR

Tabel 4.1 Pengujian nilai PSNR Triple Transposition Vigenere Cipher dan MLSB 38 Tabel 4.2 Hasil Pengujian MSE dan PSNR Meggunakan Fungsi Hash dan Metode MLSB 39 Tabel 4.3 Jumlah maksimal karakter pesan 41

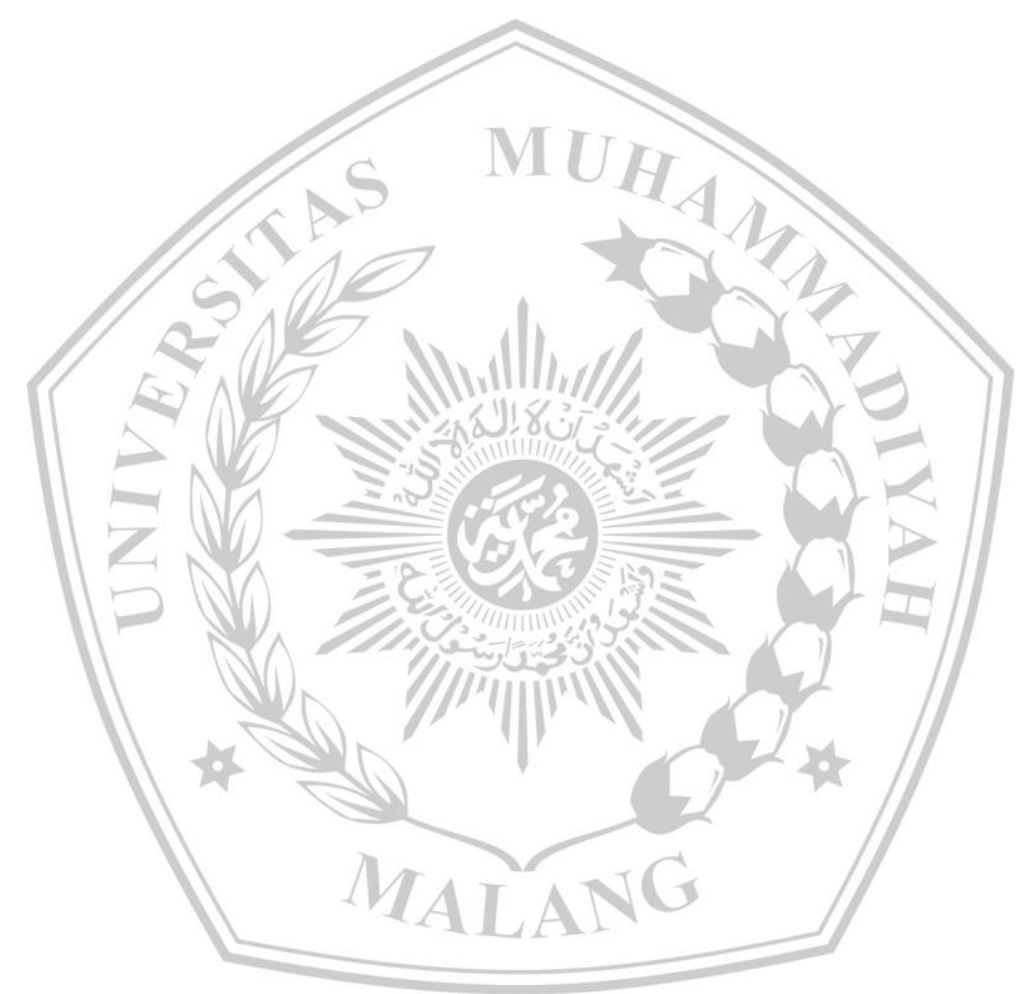




\section{Daftar Pustaka}

[1] M. A. I. Pakereng et al., "Perancangan dan Implementasi Aplikasi CryptoSteganography untuk Pengamanan Pengiriman Gambar Menggunakan Vernam Cipher, RSA dan LSB Embedding Artikel Ilmiah Perancangan dan Implementasi Aplikasi Crypto-Steganography untuk Pengamanan Pengiriman Gambar Me,” no. 672008054, 2014.

[2] J. I. Sari, Sulindawaty, and H. T. Sihotang, "Implementasi Penyembunyian Pesan Pada Citra Digital Dengan Menggabungkan Algoritma HILL Cipher Dan Metode Least Significant BIT (LSB)," J. Mantik Penusa, vol. 1, no. 2, pp. 1-8, 2017.

[3] C. Paper and S. N. Indonesia, "Teknik Steganography Dengan Metode Least Significant Bit ( Lsb ),” no. September 2015, 2016.

[4] M. Z. Abu, "Modified Least Significant Bit ( MLSB )," Ccsnet, vol. 4, no. 1, pp. 60-67, 2011.

[5] Inayatullah, "Analisis Penerapan Algoritma MD5 Untuk Pengamanan Password," J. Algoritm., vol. 3, no, 3, pp. 1-5, 2007.

[6] A. Kumar and R. Sharma, "International Journal of Advanced Research in A

Secure Image Steganography Based on RSA Algorithm and Hash-LSB Technique," Int. J.Adv. Res. Comput. Sci. Softw. Eng., vol. 3, no. 7, pp. 363-372, 2013.

[7] A. A. Lubis, N. P. Wong, I. Arfiandi, V. I. Damanik, and A. Maulana, “ Steganografi pada Citra dengan Metode MLSB dan Enkripsi Triple Transposition Vigenere Cipher," Steganografi pada/Citra dengan Metod. MLSB dan Enkripsi Triple Transposition Vigenere Cipher, vol. 16, no. 2, pp. 125-134, 2015.

[8] A. Sulistyanto, T. Informatika, F. T. Informasi, and U. B. Luhur, "Digital Watermarking Pada Citra Menggunakan Metode Modified Least Significant Bit ( MLSB ) Dengan Penyebaran Pesan Secara Acak Menggunakan Metode Linear Congruential Generator ( LCG ): Studi Laboratorium ICT Terpadu Universitas BUDI LUHUR."

[9] J. Sembiring, "Analisis Algoritma Sha-512 Dan Watermarking Dengan Metode Least Significant Bit Pada Data Citra," Semin. Nas. Sist. Inf. Indones., pp. 2-4, 2013.

[10] M. M. Emam, A. A. Aly, and F. A. Omara, "An Improved Image Steganography Method Based on LSB Technique with Random Pixel Selection," Int. J. Adv. Comput. Sci. Appl., vol. 7, no. 3, pp. 361-366, 2016. 


\section{UNIVERSITAS MUHAMMADIYAH MALANG FAIKULTAS TEKNIK PROGRAM STUDI TEKNIK INFORMATIKA J. Raya Tlogomas 246 Malang 65144 Telp. 0341 - 464318 Ext. 247, Fax. 0341 - 460782}

\section{FORM CEK PLAGIARISME LAPORAN TUGAS AKHIR}

Nama Mahasiswa : Alfian Yuniarto

NMM

: 201310370311245

Judul TA

: Steganografi Dalam File Citra Menggunakan Fungsi Hash Dan

Metode MLSB

Hasil Cek Plagiarisme dengan Turnitin

\begin{tabular}{|l|l|c|c|}
\hline No. & \multicolumn{1}{|c|}{ Komponen Pengecekan } & $\begin{array}{c}\text { Nilai Maksimal } \\
\text { Plagiarisme (\%) }\end{array}$ & $\begin{array}{c}\text { Hasil Cek Plagiarisme } \\
(\%)\end{array}$ \\
\hline 1. & Bab 1 - Pendahuluan & $10 \%$ & 8 \\
\hline 2. & Bab 2 - Daftar Pustaka & $25 \%$ & 73 \\
\hline 3. & Bab 3 - Analisis dan Perancangan & $25 \%$ & 4 \\
\hline 4. & Bab 4 - Implementasi dan Pengujian & $15 \%$ & 0 \\
\hline 5. & Bab 5 - Kesimpulan dan Saran & $5 \%$ & 20 \\
\hline 6. & Makalah Tugas Akhir & $20 \%$ & \\
\hline
\end{tabular}

Mengetahui,

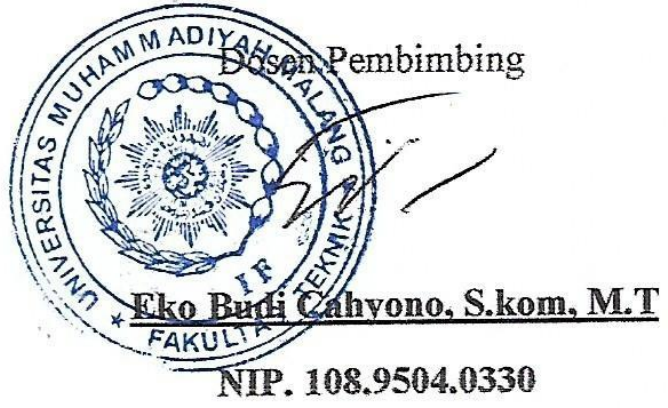

